\title{
Reality of insecurity in Psalm 7 and Christian mission in Nigeria
}

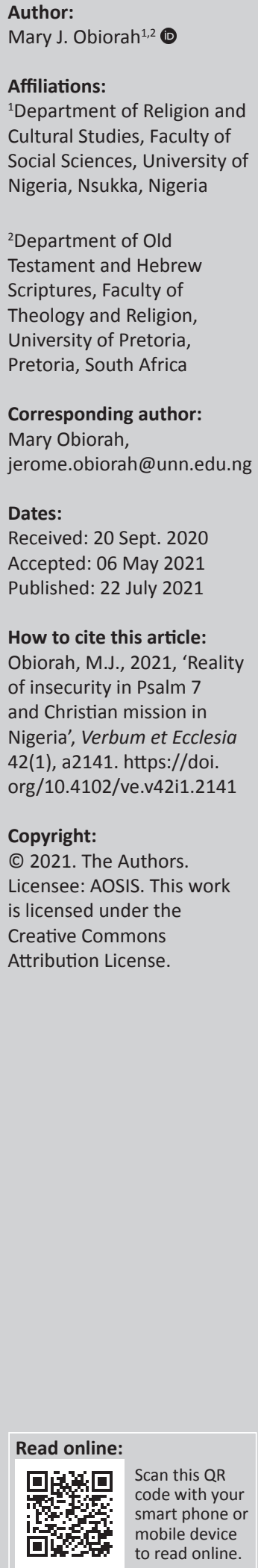

\begin{abstract}
The psalmists in their expressions of anguish, firm trust in God and entreaties conveyed varied aspects of insecurity in their lives. They were threatened by fellow human beings and inexplicable natural disasters. These, however, did not deter them from their unflinching faith in God. Psalm 7, chosen for this study, is an individual psalm of lament; it is replete with realities of insecurity in the life of the petitioner. Similar life situations are experienced by many Christians in Nigeria as they carry out their mission. A literary approach in the design of biblical exegesis was adopted in this study. It is an exegetical method that analyses the syntactical procedure in the text and how the ancient writer persuasively articulated his message. The aim of this study is to understand the message of Psalm 7 for contemporary Christians in Nigeria who are beset by various forms of insecurity, which threaten their lives.

Intradisciplinary and/or interdisciplinary implications: Reality of insecurity in Psalm 7 is a biblical study of the experience of insecurity in the Old Testament and in Nigeria. It is discovered that in both contexts, victims hold tenaciously to their faith in God despite their sufferings. Disciplines implicated are Sociology and Political science.
\end{abstract}

Keywords: Psalm 7; insecurity; Christian; Islam; Nigeria; suffering; Old Testament.

\section{Introduction}

Conspicuous in the psalter and with vivid and specific literary traits are psalms of individual and communal laments. The petitioners articulate their precarious life situations in words that are replete with horrendous images that portray their insecurity. These earnest and passionate prayers are addressed to God whom the psalmists firmly believe is their only saviour and hope of survival (Alonso-Schökel \& Carniti 1992:229). The perpetrators of their anxiety are primarily God's enemies and this spurs the confidence of the psalmists that God will be fully involved in subduing and eradicating the menace generated by these evildoers. Incapacitated and threatened by these ungodly persons who are by their actions practical atheists, their sense of insecurity heightens and their prayers for deliverance are magnified in proportion to the danger they experience.

Insecurity destabilises personal and communal projects and creates uncertainties; it hitches all aspects of progress and personal beliefs are greatly endangered. Weaklings in faith lose their poise and question the basis of their beliefs. Psalm 7 chosen for this study is a prime example of an individual lament, which depicts a person beset by untold perils in life. The psalmist, amidst his challenges, demonstrates unwavering faith in Yahweh, whom he invokes with inspiring titles. His determination to persist in righteousness makes him distinct from his opponents and draws him closer to his God.

The life situation of the petitioner in Psalm 7 reflects to some extent the conditions of many Christians in Nigeria, especially those who live in Muslim-dominated parts of the country, who suffer unduly because of their faith. Their forms of persecution range from marginalisation in a nation that belongs to them, loss of personal property, denial of basic rights, physical abuse and loss of their own lives. Their missions are adversely affected and some are impelled to relinquish their faith. In spite of collaborative efforts amongst different Christian denominations through their common forum, Christian Association of Nigeria (CAN), and dialogue with their primary opponents, adherents of Islam, their predicaments are still to reach a lasting solution.

Like many parts of Christian Sacred Scripture that offer solace in moments of trials, Psalm 7 epitomises an experience of insecurity by one who understands his faith and has made a fundamental option to remain faithful. The present study of this psalm of lament aims at elucidating its message for Christians in Nigeria who desire so much to continue their mission but 
they have setbacks militating against it. The tripartite division of this article begins with a literary study of the Hebrew text of Psalm 7 to succinct presentation of various forms of persecution of Christians in Nigeria and a synthesis of the salient message of the psalmist.

\section{Understanding Psalm 7 A translation of Psalm 7}

1. A Shiggayon of David which he sang to the Lord concerning Cush, a Benjaminite.

2. O Lord my God, in you I have taken refuge; save me from all who pursue me, and rescue me.

3. Otherwise, he tears me into pieces like a lion, he tears away and there is no rescuer.

4. O Lord my God, if I have done this, if there is wrong in my hands.

5. If I have repaid my friend with evil, or plundered my foe without cause.

6. Let my enemy pursue and overtake me, and trample my life to the ground, and make my honour dwell in the dust (Selāh).

7. Rise up O Lord in your anger; lift yourself against the fury of my foes; awake, O my God, you have appointed a judgement.

8. The assembly of the peoples gather around you, and against it return on high.

9. The Lord judges the peoples; judge me, O Lord, according to my righteousness, and according to my integrity that is in me.

10. Let the evil of the wicked come to an end; but establish the righteous, you who test hearts and minds, $\mathrm{O}$ righteous God.

11. My shield is in God, who saves the upright of heart.

12. God is a righteous judge, a God who passes sentence every day.

13. If one does not repent, he (God) will sharpen his sword; he has bent and strung his bow.

14. He has prepared his deadly weapons, making his arrows burn.

15. See he is pregnant with trouble, and conceives evil and gives birth to lies.

16. He dug a pit, and he dug it; he falls into the pit he has made.

17. His evil will return on his head and on the crown of his head his violence will descend.

18. I will praise the Lord according to his righteousness; and I will sing to the name of the Lord Most High.

(Author's own translation)

\section{Dynamic features of Psalm 7}

Verse 1 of this psalm connects the text to a particular event in the life of David. According to this superscription, the psalm is David's prayer to the Lord against a certain Cush, a Benjaminite, an event which is not narrated explicitly in the OT, even though David experienced conflicts from the
Benjaminites (cf. 1 Sm 24-26; 2 Sm 16:5; 20:1). Some ancient versions of the Bible such as the Septuagint, Vulgate, Aquila, Theodotion and Symmachus read Cushite, thus linking the text to the narrative in 2 Samuel 18:19-31. In that narrative, a certain Cushite brought to David the sad news of the death of Absalom. The content of this psalm, however, suggests a reaction to an attack of enemies instead of a dirge at the news of the death of a son. This perception better explains traces of life-threatening danger that pervade the psalm.

Reading through Psalm 7, clusters of ideas as the text progresses segment the psalm into clear sections that constitute correlated parts of this direct address to God by a desperate petitioner. Beginning in verse (v.) 2 with an initial personalised divine name, $Y H W H$ 'ěHWH' 'O Lord my God', construed as vocative, the psalmist makes a passionate plea to God to be delivered from his foes. The Tetragrammaton, YHWH, occurs seven times, indicating perfection and completeness, in this Psalm 7 (cf. vv. 2a, 4a, 7a, 9a, 9b, 18a, $18 \mathrm{~b})$. The psalmist protracts his earnest entreaty to v. 3 with a conjunctive particle, pen 'otherwise', having its antecedent in v. 2. Thus, vv. 2-3 are linked by this prayer of deliverance with which the psalmist begins his poem. (Reading through Ps 7 clusters of ideas segment the psalm into clear subsections. These sections correlate with what one finds in other individual laments where a desperate petitioner addresses Yahweh. The psalm commences with an invocation of Yahweh: YHWH'élōhay 'O Lord my God'. The psalmist makes a passionate plea to God that he should deliver him from his foes. The Tetragrammaton, $\mathrm{YHWH}$, occurs seven times, indicating perfection and completeness (cf. vv. 2a, 4a, 7a, 9a, $9 b, 18 a, 18 b)$.

Verse 4 begins with the same divine name $Y H W H$ 'élōhay 'O Lord my God' as in v. 1. However, the particle, 'im ['if'] in the first part of v. 4, which follows these names and is repeated in v. $4 \mathrm{~b}$ and v. $5 \mathrm{a}$, signals a new development in the text. There are consequently three 'if' clauses in vv. 4-5 and their conjoined apodosis, the main sentence, is in v. 6. A compound sentence runs through the three verses of 4-6 in which the psalmist avers his innocence in the face of obvious anxiety. He is utterly convinced of his virtuousness such that the expressed consequence in the main clause (v. 6) entails the loss of his life. The progressive unfolding of the contents of vv. $4-5$ is worth noting, which moves from general idea to concreteness. The first part of v. 4 is very general and seems an introduction to the remaining two conditional clauses. The second part of v. 4 gives inkling to the meaning of v. $4 a$. In v. $5 \mathrm{a}$ the speaker becomes more explicit and most clear in v. $5 b$, thus making a persuasive claim of rectitude amidst uncertainty.

Three imperatives qûmāh ['rise up'], hinnāśēh ['lift yourself'] and $w^{e s} \hat{u} r \bar{a} h$ ['and awake'] in v. 7 and similar imperative, soptện $[$ ['judge me'] in v. 9, all hint at an introduction of something different from the preceding verses but not disconnected from them. Another imperative, šûbāh ['return'], in v. 8, addressed to God, confirms a new 
development in the Psalm; thus, vv. 7-9 are linked by these imperatives, which are directed to YHWH. Moreover, recurrent in this segment of the poem is the concept of 'judging', expressed twice with the root špt 'to judge'; first as a noun, mišpat 'judgement' in v. 7, and as an imperative sopțen $\hat{\imath}$ in v. 9. In v. 8, the gathered assembly is destined for judgement. Finally, in v. 9, the idea of judging is further expressed with the verb yādîn. In addition to this distinct feature of vv. 7-9 is the use of the divine name YHWH at the beginning (v.7) and two more occurrences at the end (v. 9). 'God's judicial activity appears in the psalms as an alternate form of his aggressive engagement on behalf of right and righteous' (Keel 1997:207-208). The plea for divine acquittal of the blameless petitioner appears to be the focus of this stanza.

The psalmist's entreaty for vindication against his foes is continued in vv. 10-12, albeit in a new dimension. The concept of 'judging' appears in the divine appellation 'élōhîm šôet șaddîq 'God is a righteous judge' (v. 12), and also in the phrases: ûbōhèn libbôt ûk'lāyôt 'you who test hearts and minds' and $w^{e^{\prime}} \bar{e} l z \bar{o}^{\prime} \bar{e} m$ bekol-yôm 'a God who passes sentence every day'. On the other hand, the newness in vv. 10-12 is in the contrast between the $r^{r} \bar{s}^{\prime} \hat{\imath} m$ 'wicked' and the șaddî 'the righteous'. This latter is predicated of both God (vv. 10,12) and those who take him as their shield (v. 11) and who are also yišrê-lēb ['upright of heart'], the group to which the psalmist avows he belongs. Outstanding in this stanza is the invocation 'élōhîm șaddîq ['O righteous God'], which encapsulates the prayers of the psalmist. The righteous prays to a righteous God; he shares in God's righteousness for he belongs to him. This contrast between the wicked and the righteous features also in the desire of the psalmist for each group: he prays that the evil of the wicked will come to an end and that God will establish the righteous (v. 10).

Verses 13-14 are a natural continuation of the preceding stanza (vv. 10-12), because in both of them the image of the just God who judges righteously and who is exasperated by moral evil is presented (Girard 1996). The righteous God is ever ready to execute his just judgement, especially on a person who fails to repent ('im-ló $\bar{o}^{\prime}$ yāšûb) of his evil deeds. With a progression of metaphors of God's judgement, the psalmist describes God's action against the godless in a language that depicts warfare (Alonso-Schökel \& Carniti 1992), all in anthropomorphic image of God that pervades the entire Psalter. Like a human armour bearer, God sharpens his sword, gets his arrow and deadly weapons ready for battle. This belligerent God fights for the righteous who takes refuge in him. Their foes are also his enemies; the psalmist accentuates this in his prayer.

In vv. 15-17, the petitioner focuses on the skirmishes of his enemy. He depicts his foe's heinous plots and their origin (Craigie 1983) with the figure of conceiving, becoming pregnant and giving birth like a woman. Unlike a woman who conceives, carries the pregnancy and eventually gives birth to a human being, the ungodly conceives trouble, carries evil in his pregnancy and gives birth to lies (v. 15).
This image of plotting evil against an innocent person is elucidated with another image of digging a pit and making it deep with the purpose of entrapping someone. The perpetrator, however, is met with a boomerang for the action backfires on him, the initiator (v. 16). 'The evil which originates with the wicked creates a fateful chain of events which ultimately turns against the offender himself' (Keel 1997:1998). This reversal of planned misfortune is articulated in a prayer and ardent desire of the psalmist in v. 17, in which the psalmist uses a word-pair, $r \bar{o}^{\prime} \breve{s}$ [head] and qodqōd [crown of head] in their correct order of the more frequent one, $r \bar{o}^{\prime}{ }^{\prime}$, preceding the uncommon word, qodqöd (Watson 1995).

The concluding prayer of praise stated in a synonymous parallelism in v. 18 highlights the key points of the psalm. It heightens the petitioner's protestation of confidence in Yahweh, which begins the psalm. The phrase, kesidqô ('according to his [God's] righteousness'), evokes the psalmist's image of Yahweh as a just judge, who vindicates the righteous. The first word 'ôdeh ['I will praise'] (from ydh) is in the cohortative, expressing the will or strong desire and resolution (Waltke \& O'Connor 1990) of the speaker to praise God whom he believes has heard his prayers; it is not necessarily an indication that he is a chorister (Terrien 2003:122). Moreover, with the divine appellation $Y H W H$ 'elyôn ['the Lord Most High'], which expresses the transcendence of God (Ravasi 1997:176), the psalmist attains the climax of all the divine names he has employed in his prayer.

Although each of the component parts $(2-3 ; 4-6 ; 7-9 ; 10-12$; $13-14 ; 15-17$; 18) of Psalm 7 forms a unique unit in the text, this is not in isolation for there is interconnection and some level of concatenation that runs through the psalm. Its composition is logically arranged and the psalmist's experience of insecurity is persuasively highlighted.

\section{Expressions of insecurity in Psalm 7}

Interjections of pain and distress directed to God by the psalmist in Psalm 7 give the reader a clue as to the life situation of the petitioner. These include $Y H W H$ 'élōhay [‘O Lord my God'] (vv. 2,4), YHWH ['O Lord'] (vv. 7, 9), 'élay ['O my God'] and 'élōhîm șaddîq [‘O righteous God'] (v. 10). In v. 10, the divine name 'élohtim with an adjective in the singular is one of the 25 examples of honorific use of this divine name, which is in plural, referring to the God of Israel (Waltke \& O'Connor 1990:122). Worth noting is a unique divine title, môš $\hat{\imath}^{\prime}{ }^{\prime}$ [he who saves] in v. 11 (cf. Dt 22:27; 28:29,31; Jdg 3:9,15; $6: 36 ; 12: 3 ; 1$ Sm 10:19; 11:3; 2 Ki 13:5; Ps 17:7; 18:42; Is 19:20; $43: 11 ; 45: 15 ; Z \mathrm{Ch} 8: 7)$. These are cries of anguish because they are invariably followed in the text by statements that show the psalmist is in dire need of divine assistance and deliverance.

In his first cry of deliverance (v. 2), the psalmist describes his condition as one who is being pursued with hostility. Employing an active participle, perhaps to portray a dramatic effect of his suffering, he calls his adversaries rōdpay ['my 
pursuers'], a word from the root $r d p$, which often has a negative connotation: 'to persecute, chase or hunt'. The details of this persecution are not communicated, but they are antagonistic enough to be compared in v. 3 with the action of a ravenous lion before his prey. Like a lion, the persecutors are poised to tear him apart. This simile illustrates 'the merciless, irresistible grasp of tyrants' (Keel 1997:86); it is an image of utter aggression.

The second segment of the psalm (vv. 4-6) suggests an aspect of this persecution. With three initial conditional statements articulated in three 'if' clauses, the petitioner seems to give an idea of his ordeal. Is he being falsely accused or persecuted? This is very credible in the three clauses, which convey the anguish of one who suffers innocently for what he did not do. He asserts his righteousness in the main clause (v. 6) of this conditional sentence with words of self-imprecation, which only a guiltless person could pronounce against himself. In v. 6 the first word transliterated as yiraddo $p$ has a strange vocalisation; it has two possible vocalisations: qal yirdōp or piel $y^{e}$ radde $p$. It is an example of lectiones mixtae (Joüon \& Muraoka 2006:16g).

In v. 7 , the psalmist calls the action of his enemies 'ebrāh ['arrogance, anger, rage, fury'] used in the plural form, 'ăbārôt, to convey the intensity of this action against him. In about 22 times, 'ebräh is employed in the Hebrew Bible for divine wrath (cf. Is 9:18; 10:6; 13:9,13; Jr 7:29; Ezk 7:19 etc.) and 12 times for human fury (cf. Gn 49,7; Is 14:6; Am 1:11 etc.). The plural form of this word occurs only three times (Ps 7:7; Job 21:30; 40:11) and all describe human wrath. In Psalm 7:7, the plural form describes 'additional human actions carried out in wrath, against which Yahweh is asked to intervene' (Sauer 1997:836). The psalmist experiences devastating anger, which he also calls $r a^{\prime}$ ['evil'] (v.10), from his enemies and this constitutes a situation of insecurity in his life.

It is impressive to note the description of his enemy's unfriendliness in vv. 15-17 with two stirring metaphors. The first is that of conceiving and giving birth, not to a living creature but to trouble, evil and lies, which are forms of enmity. It calls to mind a possible false accusation mentioned in vv. 4-5. The second metaphor is the act of digging a pit to ensnare someone. Šahat (pit v. 16b) used in the text means very often in the OT a deliberately dug pitfall (cf. Ps 9:15; 35:7; 94:13) (Keel 1997:72); it is parallel to bôr (cistern, pit; v.16a) only here in the OT and it also means a pitfall. Both metaphors of conceiving evil and digging a cistern allude to hateful attitude of the psalmist's foes that endanger the life of the petitioner and create anxiety.

Further expressions of insecurity in Psalm 7 are seen in the terms that the psalmist uses for his enemies. He has various names for his opponents and these names convey how he perceives his life situation. In v.2 he calls them rōdpîm from $r d p$, which connotes an active pursuit of a person with hostile intent (Frevel 2004:343). In the Book of Psalms, this word is used exclusively for adversaries of an individual and it stands also for a static image of mortal danger afflicting the psalmist (Frevel 2004:349). A more general term ('ôyēb) for enemy occurs in v. 6 . In vv. 5 and 7, the psalmist calls them persons who show hostility towards him, șôr rîm, which is qal active participle from ssr; this generally means to show hostility towards a person (Jenni 1997:1098). In v. 10, the psalmist uses a plural adjective, $r^{`} \bar{s}^{\prime} \hat{\imath} \mathrm{m}$ ['wicked'] for his enemies. It is a very frequent word, occurring about 82 times in the psalter, for a person who is characterised by wickedness, who is diametrically opposed to the righteous and who lives as a practical atheist (Carpenter \& Grisanti 1997:1202). The psalmist is fully aware of this spitefulness surrounding him and he responds in various ways.

\section{Response to a state of insecurity in Psalm 7}

The initial response of the psalmist is to establish a firm rationale for his prayer for help amidst hostile situations. This he does with affirmations of confidence in Yahweh whom he invokes with various titles (cf. vv.2,4,7,8,10,18). Firstly, in his protestation of confidence in Yahweh is to use a common phrase in the Psalms: $b^{k} k \bar{a}$ hạsîtî ['in you I take refuge'] (v. 2), which occurs frequently at the beginning of some Psalms of Lament (cf. Ps 31:1; 71:1; 57:1; 144:2) or in the body (cf. Ps 17:7; 61:3; 142:5; 143:9) and rarely at the end (cf. Ps $25: 20 ; 141: 8)$. He has recourse to God whom he believes will be his hiding place, a place of refuge. Similar to this is an expression in v. 11, māḡinnî 'al-'élōhîm ['my shield is my God']. This defensive weapon, māgèn ['the symbol for the protective legal aid'] (Kraus 1993:173), occurs 15 times as a divine epithet in the OT and 12 of these are in the Psalms (cf. Ps 3:4; 7:11; 18:31; 28:7; 33:20; 59:12; 84:12; 89:19; 115:9,10,11; 119:114; 144:2); the rest are Genesis 15:1; Proverbs 2:7; 30:5. God is a defensive weapon against enemies. In Psalm 7, the psalmist perceives his life situation as warfare and he believes that God will protect him. He is being pursued by his foes and he runs to God for protection.

The petitioner's entreaty for help tends to reflect the perceived nature of his enemies and their antagonism. Hence, he uses words that reveal his precarious situation. In v. 2, for instance, he employs two verbs, in the imperative mood addressed to Yahweh, which show the danger facing him. He asks Yahweh

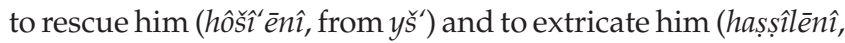
from $n s ̦ l$ ). Later in v. 11 he calls Yahweh môš $i^{a^{\prime}}$ ['he who saves'], from the same root as hôšr' ênî. As if Yahweh were in deep slumber and needed to be awaken from it, the psalmist addresses him in v. 7 with three verbs appropriate for arousing a person from sleep: qûmāh ['rise up'], hinnāséeh ['lift yourself'] and 'ûrāh ['awake'], all imploring 'God to act in the most urgent tones' (Craigie 1983:101). When God's response to prayers appears to delay, he seems to be sleeping. Finally, in v. 10 the psalmist prays that the evil of the foes come to an end (Matthews \& Benjamin 1997:65).

The supplicant substantiates these serious and passionate requests for divine intervention in his peril by evoking his personal innocence (vv. 5-6), righteousness and integrity 
(v. 9). His life as a righteous person (saddîq), a participation in God's righteousness (Rosendal 2013:50), is at variance with the life of his enemies (Mays 1994:64) whom he depicts as wicked people $\left(r^{\circ} \bar{s}^{\prime} \hat{\imath} m\right)$. He also evokes Yahweh's righteousness and justice, for he is a righteous God (vv. 10.18) and he is just in his deeds (vv. 13-14); this 'guarantees the worshipper's protection and help' (Weiser 1962:138).

In v. 8, the Hebrew imperative of second person masculine singular (šûbāh) has different translations in some versions of the Bible. The Septuagint epistrepson and the Vulgate regredere reflect this Hebrew imperative, which means 'return'. Similar translation is reckoned in The New American Standard Bible, The New Jerusalem Bible, The New King James, La Sacra Bibbia della Conferenza Episcopale Italiana (CEI) and many others. The critical note of Biblia Hebraica Stuttgartensia suggests the reading of šêbāh (imperative second person masculine singular, from the root yšb ['to dwell, sit']) instead of šûbāh. This suggestion most probably is behind the translation 'take your seat' or similar phrases in many modern translation and commentaries. The Hebrew txt, which is clarified in the explanation, is retained in the translation here. The petition prays that God may return on high and execute justice on his behalf as in a court of law. One can elicit the argument of the psalmist in this way: as God is a just judge and righteous in his deeds and the psalmist is innocent, God will surely answer his prayers for help in this apprehensive situation. This confidence in God expressed in various forms in his prayer prompts the ardent desire to praise God (v.18) (Kraus 1993:176).

Genre critics of the Book of Psalms identify Psalm 7 as an Individual Lament (Seybold 1990:116; Gunkel \& Begrich 1998:121) and that it exhibits all the characteristics of this group. The features include a well-calculated invocation of divine name that shows that these psalms are entreaties addressed to God, description of the petitioner's life situation that generated the lament, prayer for help, affirmation of trust in God, arguments to motivate God's intervention, declarations and desire or vow to praise God (Seybold 1990:116). In his experience of insecurity, which is almost palpable in the text, the psalmist articulates all these traits of an Individual Lament. The nexus that links all these constituent parts is his sense of insecurity expressed therein.

\section{Insecurity and Christian mission in Nigeria}

Nigeria, a multi-ethnic and religious nation with a teeming population of over 200 million inhabitants (cf. Worldometer 2020), is not without recurrent strife emanating from its interwoven sectors: political, ethnic and religious. These are, indeed, interconnected because they tend to be naturally arranged according to the geographical milieus of this nation. The northern part, for instance, is predominantly Hausa and cognate ethnic groups; the western part is Yoruba and the dominant ethnic group of south-east is Igbo. Each of these three geographical areas has its dominant religion and political affiliation. The three major religions in the country are Christianity, Islam and Traditional Religion. Whilst adherents of the first two have divergent tenets that often spawn intolerance and frictions, beliefs of Traditional Religion infiltrate into the other two religions without noticeable physical violence. Syncretism amongst Christians and Muslims who oscillate between their religions and Traditional Religion does not affect the lives of the people the way violence between Christians and Muslims does. Vulnerability of Christians, whose religion invariably promotes non-violence and dialogue with opponents, exposes them constantly to untold assaults that generate insecurity and adversely affect their religious freedom and mission (Iwuoha 2018:47). Like the psalmist in Psalm 7, many Christians in Nigeria frequently cry out to God for help against their enemies.

Forms of insecurity experienced by Christians often emanate from fanatical ideology of adherents of Islam (Oguejiofor 2017:39), particularly the group associated with Boko Haram insurgents, who tenaciously believe that non-Muslims are infidels destined for extermination if they resist forceful conversion (Okonkwo 2017:31). Thus, they are intolerant and overtly scorn and reject Christians; some Christians also manifest similar attitude towards non-Christians. On their part, Christians suffer this rejection and its psychological impact in the society. Christians living in Muslim-dominated areas of the country where they are not accepted feel like loners. They are treated like aliens in their own country, and they are impelled to question their sense of belonging. Some of them are openly jeered at and mocked because of their religion: a situation that makes some of them lament like the psalmist: mā̄öinnî 'al-'élōhîm ['my shield is in God'] (Ps 7:11). Their Muslim brethren treat them like outsiders and are unwilling to work and live with them in the same establishment.

In a normal and just society where human rights are recognised and observed, anybody qualified for a job or post in an establishment is employed or placed in that post. However, rejection of Christians in Muslim-dominated parts of the country engenders a form of insecurity that subjects them to solely self-employment in order to earn their living (Çancı \& Odukoya 2016:102). Although they hold genuine degrees and certificates, their less qualified compatriots are preferred to them on the basis of religious discrimination. Their lament can be likened to the psalmist's invocation: 'élōhîm șaddîq ['O righteous God!'] (Ps 7:10). Sometimes, Christians who are employed can be deposed anytime a Muslim manifests an interest in the job or post. Others are willfully denied of promotion in a job they have served for many years.

It is not uncommon to see where Christians are not allowed to practise their religion openly like their Muslim counterparts (Nwaomah 2011:98). Some who have to wear certain stipulated garments as an outward sign of their belief are prevented from appearing in them in public, even when Muslims freely wear theirs wherever they deem fit. Christian 
religious symbols such as the cross, statue and holy pictures are strictly prohibited even in Christian edifices. Bells in Christian churches dare not ring to summon Christians to prayers and other devotions but Muslim's call for prayers loudly sounds at all the hours of their prayers. Christian gatherings for prayers are scorned and dispelled because they are considered as assemblies that offend Allah.

Closely related to this is Muslims' unhealthy proselytisation, which creates fear and volatility amongst Christians. These proselytisers compel them under the grave pain of death to renounce their Christian faith and convert to Islam. Obsessive Muslims believe that Christians are doomed forever and every effort should be made to bring them to the true faith; thus, they undertake the process of coerced conversion that is utterly inhuman and degrading to human dignity. On the other hand, any convert from Islam to Christianity falls into the great danger of losing his or her life. Muslims pursue to eliminate them in life as the enemies of the psalmist did (Ps $7: 2$ ). Some are pressurised to flee their own land, abandon their inheritance and relocate to another place where they can be free to worship God according to their convictions.

This religious persecution takes another dimension when Christians are not permitted to procure land and erect their own places of worship and activities. In addition, they cannot convert the already existing edifices into religious premises for their prayers and meetings. Some have to use their private houses and silently hold their religious services therein. Similarly, Christians are not authorised to build Christian places of learning where their children can be trained; thus, Christian education is strictly prohibited in some stringently Muslim parts of the country. As a consequence, they are compelled to send their wards to public schools where their faith is greatly endangered because of Muslim influence. Other Christian centres such as pastoral institutes for ongoing formation in Christian faith and training of pastoral workers such as priests, catechists and others are out of place in these places. All these are meant to stifle their faith and make them succumb to pressure created by unduly zealous Muslims who are perpetrators of insecurity of Christian mission.

Some existing Christian properties, where these were previously allowed to stand, like church buildings, schools, private homes, commercial edifices, industries and other sources of earning one's living are constantly under siege. Many churches of various Christian denominations have been burnt without recognition. Some of these belongings were destroyed when the worshippers were in full session for their religious services. This has aggravated their pain and trauma. They are helpless, unprotected by their political leaders who should care for all irrespective of religion and ethnicity. In desperation, many have used words akin to that of the psalmist: $w^{e^{\prime}} \hat{e} n$ mașsîl $\left[{ }^{\prime} \ldots\right.$ and there is no rescuer'] (Ps 7:3).

Yet another device of instilling fear and sense of insecurity in the lives of most Christians is through an organised crime of kidnapping some persons and demanding huge amount of money from their relatives. Although this means of extortion is not perpetrated only by enemies of Christians and Christians are not solely affected, these foes have appropriated it for they find it a quick lucrative venture and perversion of Christian mission. Paradoxically, they demand ransom from those they consider as infidels. They attack Christian religious and formation houses, forcefully drag some away and keep them in hazardous ambience until acquaintances of their victims are able to rescue them.

Kidnappers and similar attacks on human lives have rendered many perpetually invalid in life. The enemies intentionally maim their victims and leave them with this indelible mark. Some can no longer be useful to themselves and to the society because they refuse to renounce their religion. Some unfortunate women are overpowered and defiled; they bear the psychological impact of this all their lives in spite of some efforts to rehabilitate them. The voice of the petitioner in Psalm 7:7 could be heard in the hearts of those afflicted as they cry to God who seems to be far away: qûmāh YHWH b b'apeka ['Rise up O LORD in your anger'].

Indiscriminate and massive killings of helpless and innocent individuals in their homes, religious precincts, places of work, by the road and other social gatherings, pervade a greater part of the insecure areas of the country. The enemies take delight in these heinous activities and feel glorious in what they understand as their achievement. Bereaved Christians have to abandon their home and look for a better place to continue their lives and those who are residents or internal migrants return to their places of origin and begin life anew (Gambo \& Omirin 2012:129). The expected consequence is a drastic reduction in the number of Christians and their activities in these insecure areas.

In their pains and insecurity that threaten their mission in the nation, Christians in Nigeria often resort to prayers like the psalmist, asking for the conversion of their enemies and an end to violence. They also seek non-violent resolution of their situation through dialogue with their Muslim compatriots (Onwukeme 2008:257). Peaceful protests against political leaders who are insensitive to the plight of the citizenry are not excluded. These take the form of written declaration of individual Christian denominations (Catholic Bishops Conference of Nigeria 2020) or collective appeal by CAN. There have been peaceful marches with placards decrying the precarious situation of Christians. Many individuals have fearlessly made their voices heard through writing, organising symposia on human rights and on peaceful coexistence (ed. Obanure 2008). The activities of Boko Haram group have also been exposed through research and many literary endeavours (Omomia 2015:58).

\section{Learning more from the psalmist}

Conspicuous in the experience of insecurity in Psalm 7 is the psalmist's unflinching confidence in God whom he invokes with a good number of titles beginning from the opening phrase (YHWH 'élōhay ['O Lord my God']) of the Psalm 
proper in v. 2 and the most striking YHWH 'elyôn ['the Lord Most High'] at the end of his prayer in v. 18. This protestation of faith in God pervades the entire psalm. The psalmist believes that God is his strong refuge (v. 2), the Saviour (v. 11), he who is ever ready to fight for those who trust in him (vv. 13-14), defensive weapon and shield for his people (v. 11). Such a firm trust in God sustains the petitioner in all his trials as he perceives the omnipotence of God over and against his foes who are equally God's enemies (Wilson 2002:193), practical atheists, $r^{r} \bar{s}^{\prime} \hat{\imath}^{\prime} m$ (v. 10). The same trust in God makes him believe that the failure of the wicked follows the operation of the order established by God at creation; a person reaps what he or she sows (Keel 1997:98). The wicked fall in the same pit they have dug for the innocent (Ps 7:16).

The psalmist remains a prime example for all who today find themselves in a predicament similar to his. He does not lose hope in God's ever ready help; he takes God as his refuge. It is of interest to observe the emphatic position, like in most psalms, of the key phrase of this psalm at its beginning in v. 2: $b^{e} k \bar{a} h \bar{a} \bar{s} \hat{\imath} \hat{\imath}$ ['in you I have taken refuge']. This sets the tone for the entire psalms that contains utterances of one who takes refuge in God. In a situation where one can possibly lose hope and renounce his or her belief, the words of the psalmist spur one on to persevere, knowing that there is a way to surmounting life challenges and this is to cling tenaciously to God.

The psalmist's firm trust in God is not an abstract and unsubstantiated ideology. He blends it with innocence of life, which he himself affirms in his prayers (Girard 1996:226). In a stanza (vv. 4-6) that relates possible false accusations from his enemies, he evokes his righteousness by unusual selfimprecations in which he prefers that he were dead rather than to have committed what he is being accused of. Furthermore, in v. 9, the same consciousness of his righteousness moves him to call upon himself divine justice, being certain of his righteousness, integrity of life and uprightness of heart (v. 11). He confidently calls himself șaddîq ['righteous'], which he recognises in his God and predicates it of him. This is the basis of his prayer: that the righteous God does not fail to heed the pleas of a righteous person, for God's righteousness is his saving love (Ravasi 1997:178). The psalmist sees himself as not belonging to the category of the ungodly who are his enemies and enemies of his God. As he belongs to God, he believes that God will surely answer and rescue him from his perils; he will emerge victorious from his dangers, praising God according to God's righteousness.

Christians in Nigeria who are persecuted and maltreated in various ways can sustain their mission by witnessing prophetic authenticity in the midst of their foes. Integrity of life strengthens their faith in God and makes them different from those who pursue them. Some have been able to gain converts from their enemies because these enemies were attracted by the resilience of their victims and their piety translated into charitable works that do not discriminate against religion or ethnic groups. Genuine Christian love shown to all differentiates Christians from their enemies and fortifies the foundations of their mission in hostile environments that abhor their belief. Unfortunately, the life styles of many Christians are not different from non-believers because these Christians are also involved in perpetrating social ills, particularly various forms of endemic corruption in the nation.

\section{Conclusion}

Variegated wilful attacks from enemies are easily perceptible in the prayers for deliverance seen in the OT psalms of both individual and communal laments. The petitioners express their ordeals in words and vivid images that convey effectively the enormity of their perils. Psalm 7 studied in this article exemplifies a threatening situation of the psalmist whose life reflects various types of sufferings experienced by many Christians in Nigeria whose mission is continuously hampered by their opponents. Like the psalmist, these ill-fated Christians express their conditions of insecurity but receive no help from those who ought to protect them.

Reading through the words of the psalmists, especially in Psalm 7, one observes that their sufferings strengthen their faith in God whom they perceive as their only saviour. The thought of this makes them run to him for deliverance and lasting protection. They understand their enemies as God's enemies, and in fact as practical atheists. Their life is at variance with that of their foes; therefore, they adhere closely to God's ways and make fundamental option to persist in this; they shun the ways of the wicked. In other words, instead of yielding to the behaviour of their adversaries who are godless in their comportment, the insecurity they experience solidifies their faith and turns them into defenders of uprightness in the society.

The righteousness of the psalmist in Psalm 7, which he expresses in various ways, remains a point of reference for many Christians in Nigeria who are constantly attacked by their adversaries, particularly fanatical Muslim groups. Their sufferings should be a source of strength and opportunities to witness to their faith, even when they are compelled to abandon their belief. Sufferings are occasions for renewal of their Christian commitment and like the psalmist they should be always ready to praise God and sing the name of the Most High (Ps 7:18).

\section{Acknowledgements}

The author is grateful to the librarians at the Blessed Iwene Tansi Major Seminary, Onitsha, Nigeria, for their assistance in this research.

\section{Competing interests}

The author declares that she has no financial or personal relationships that may have inappropriately influenced her in writing this article. 


\section{Author's contributions}

M.J.O. is the sole author of this research article.

\section{Ethical considerations}

This article followed all ethical standards for research without direct contact with human or animal subjects.

\section{Funding information}

This research received no specific grant from any funding agency in the public, commercial or not-for-profit sectors.

\section{Data availability}

Data sharing is not applicable to this article as no new data were created or analysed in this study.

\section{Disclaimer}

The views and opinions expressed in this article are those of the author and do not necessarily reflect the official policy or position of any affiliated agency of the author.

\section{References}

Alonso Schökel, L. \& Carniti, C., 1992, I Salmi, vol. 1, Edizioni Borla, Rome.

ÇancI, H. \& Odukoya, O.A., 2016, 'Ethnic and religious crises in Nigeria: A specific analysis upon identities (1999-2013)', African Journal of Conflict Resolution 16(1), 87-110.

Carpenter, E. \& Grisanti, M.A., 1997, 'rš', in W.A. VanGemeren (ed.), New international dictionary of Old Testament theology and exegesis, vol. 3, pp. 1201-1204, Paternoster Press, Carlisle.

Catholic Bishops Conference of Nigeria, 2020, Press releases, viewed n.d. from https:// cbcn-ng.org/pressrelease.php.

Craigie, P.C., 1983, Psalms 1-50, Word Biblical Commentary, vol. 19, Word Books, Waco, TX.

Frevel, C., 2004, 'rādap', in G.H. Botterweck (eds.), Theological Dictionary of the Old Testament, vol. 13, pp. 340-351, Eerdmans, Grand Rapids, MI.

Gambo, Y.L. \& Omirin, M.M., 2012, 'Ethno religious conflict and settlement pattern in Northern Nigeria', Mediterranean Journal of Social Sciences 3(3), 129-135.

Girard, M., 1996, Les Psaumes redécouverts: De la structure au sens, 1-50, Édition Bellarmin, Québec.
Gunkel, H. \& Begrich, J., 1998, Introduction to Psalms: The genre of the religious lyric of Israel, Mercer University Press, Macon, GA.

Iwuoha, C.M.A., 2018, 'Islamic fundamentalism and the Nigerian Nation State', The Nigerian Journal of Theology 32, 43-59.

Jenni, E., 1997, 'șrr', in E. Jenni \& C. Westermann (eds.), Theological Lexicon of the Old Testament, vol. 3, pp. 1098-1099, Hendrickson, Peabody, MA.

Joüon. P. \& Muraoka, T., 2006, A Grammar of Biblical Hebrew, Subsidia Biblica vol. 27, Editrice Pontificio Istituto Biblico, Roma.

Keel, O., 1997, The symbolism of the Biblical World: Ancient Near Eastern Iconography and the Book of Psalms, Eisenbrauns, Winona Lake, IN.

Kraus, H.-J., 1993, Psalms 1-59: A Continental Commentary, Fortress Press, Minneapolis, MN

Matthews, V.H. \& Benjamin, D.C., 1997, Old Testament Parallels: Laws and stories from the ancient near east, Paulist Press, New York, NY.

Mays, J.L., 1994, Psalms, John Knox Press, Louisville, KY

Nwaomah, S.M., 2011, 'Religious crises in Nigeria: Manifestation, effect and the way forward', Journal of Sociology, Psychology and Anthropology in Practice 3(3), 94-104.

Obanure, C. (ed.), 2008, Religion, violence and conflict resolution in Nigeria, Catholic Theological Association of Nigeria, Aboki Publishers, Markurdi.

Oguejiofor, J.O., 2017, 'The challenge of Islam in the new era of evangelization', The Nigerian Journal of Theology 31, 39-50.

Okonkwo, C.C., 2017, 'Key issues in the Boko Haram's religious violent extremism and Islamic militancy in Nigeria: Lest we miss the story', Ministerium 3(1), 1-33.

Omomia, A.O., 2015, 'Religious fanaticism and Boko Haram insurgency in Nigeria: Implications for national security', Journal of Advocacy, Research and Education 2(1), 58-73.

Onwukeme, V., 2008, 'Muslim-Christian religious violence in Nigeria: A Christian response based on Matt 5:44', in C. Obanure (ed.), Religion, violence and conflict resolution in Nigeria, pp. 245-261, Aboki Publishers, Markurdi.

Ravasi, G., 1997, II Libro dei Salmi: Commento e Attualizzazione 1: 1-50, Edizion Dehoniane, Bologna.

Rosendal, B., 2013, '....according to thy righteousness: The righteousness of God as motivation in the Hebrew Psalms of lamentation', Scandinavian Journal of the Old motivation in the Hebrew
Testament 27(1), 43-52.

Sauer, G., 1997, “'ebrāh,”' in E. Jenni \& C. Westermann (eds.), Theological Lexicon of the Old Testament vol. 2, pp. 835-836, Hendrickson, Peabody, MA.

Seybold, K., 1990, Introducing the Psalms, T\&T, Edinburgh.

Terrien, S., 2003, The Psalms: Strophic structure and theological commentary, Eerdmans, Grand Rapids, MI.

Waltke, B.K. \& O'Connor, M., 1990, An introduction to biblical Hebrew syntax, Eisenbrauns, Winona Lake, IN.

Watson, W.G.E., 1995, Classical Hebrew poetry: A guide to its technique, Sheffield Academic Press, Sheffield.

Weiser, A., 1962, The Psalms: A commentary, The Westminster Press, Philadelphia, PA

Wilson, G.H., 2002, Psalms vol.1: The NIV application commentary, Zondervan, Grand Rapids, MI.

Worldometer, 2020, Nigeria population, viewed from https://www.worldometers info/world-population/nigeria-population/. 